\title{
Militarism: Force, Class and International Conflict
}

\section{Robin Luckham}

\section{Introduction}

In the first article on this subject (IDS Bulletin, Volume 8 No. 3) it was argued that militarism in the Third World is closely associated with the expansion of capital in the world economy. Let us now look at the violence and armed struggle which has accompanied this expansion. It is a grim picture. For the past 30 years the major world powers have been locked in nuclear stalemate, restrained only by their fear of a holocaust made increasingly terrifying by the incessant arms race. The struggles between them have often been diverted to the periphery where violent upheavals-coups, revolutions, strikes, communal rioting, civil wars and wars between rival states-are commonplace. This is a matter for concern if only because human beings in their thousands, tens of thousands, hundreds of thousands and millions have been slaughtered in the process: whether by their own compatriots or ruling classes, as in Uganda, Argentina, Indonesia or Cambodia; or by the direct intervention of imperial powers as in Vietnam. The social and economic costs of violence, social disruption, warfare and movements of population on the scale they have occurred in the Third World over the past three decades are almost incalculable.

Peace is a realistic programme only if it is sought through an understanding of the political and economic forces which create struggles for domination. The military is a crucial instrument in such struggles: both as an agent of internal repression and international domination; and (on the whole less frequently) of radical social change and national liberation.

There are two ways of approaching the problems of peacekeeping. The first is more cautious and incremental: how, given existing forms of force, of class conflict, of state and international organisation, can conflict be averted, arms races be kept under control and the human and material costs of international conflict beminimised? The secondlooks at things more comprehensively: what transformations in class structure, military, state and international organisation would be required to assure conditions of lasting peace, both nationally and internationally?

The arguments of this paper suggest that the patterns of accumulation which prevail in the world economy, the existing forms of force and the present organisation of the international system of nation states, severely limit the scope for international agreement on arms control and conflict resolution of the first (incremental) kind. In addition, the present international system is based on a distribution of economic resources and of political and military power that systematically disadvantages the Third World and which the people of the latter will not for long be able to accept.

These limits and conflicts are described below. It is a much more difficult task to suggest alternatives. What forms of force and of popular mobilisation can negate the power to coerce professional military organisations? How can the nexus between armaments and international capital accumulation be broken? How can existing international institutions and the prevailing international distribution of power be changed without precipitating a nuclear holocaust? This paper does not pretend to give ready answers.

\section{Military professionalism, class and uneven develop- ment}

Class struggle is endemic in development. But the form and direction it takes is deflected by the major fractures within and between social formations created by uneven development. The expansion of capital from the capitalist core to the periphery disrupted the entire social fabric of the latter. Not only did it destroy old modes of production and replace them by new international forms of exploitation, but also it triggered off a series of political upheavals: war, colonial conquest, nationalism, inter-communal conflict and revolution.

At a national level these conflicts encompass the struggles between class and class but extend well beyond them. At international level conflict is inherent in the existence side by side of states dominated by different classes and modes of production, though as the Sino-Soviet split reminds us this is not the only way international differences arise. Nationalism is a phenomenon one ignores at one's peril. Yet it is profoundly contradictory in its nature. On the one hand it was itself internationalised by the expansion of the core capitalist countries into the periphery, providing the ideological charter of the nation-state, the political form of bourgeois society par excellence. Nevertheless, nations also demark major fractures in the international system. Nationalism was the rallying cry for the dismantling of colonial empires. In most Third World countries it 
symbolises the revolt of the periphery against the international centre. It is sustained by an international stratification between nations in terms of the power, status and economic resources they command. And the major revolutions which have taken place in the Third World-China, Vietnam, Cuba, Mozambique etc.-were not only social but also national, this being a major ingredient in their success.

The military has a particular role in all this because of the functions of organised force in carrying out (and repressing) internal conflict, in international stratification and in international war and peacemaking. Its institutional format reflects the contradictions inherent in the international system. On the one hand it is the most international of professions. The similarities between military elites, the brotherhood of arms, the multiple interconnections between them created by training and service abroad might seem to suggest that they are an important element in a new international class structure. Yet armies are the instruments of individual states, have national rather than international command structures and often develop strong nationalist ideologies. Their interstitial position between the nation State and the international system is critical in reproducing both.

The existing literature on the military in the Third World fails almost completely, however, to establish the connections between the military's position in the class structure, its institutional characteristics and its international dimensions. Insofar as it deals with the subject of class at all it does so in terms of the alleged consequences of the recruitment and social origins of the officer corps. Officers are either said to be conservative because they originate from the upper levels of the class structure-an argument that was popular in the past with radical critics of the military-or they are said to be part of the "new middle class', which brings about modernisation.

A sophisticated attempt by Huntington (1968, chapter 4) to synthesise these arguments in terms of different stages in modernisation postulates that when middle-class groups begin to challenge traditional landed oligarchies, the military plays a progressive role in dislodging the latter; but when lower class groups begin to organise, the military increasingly plays a repressive role in defence of established class interests. The military supports bourgeois revolutions but opposes socialist ones, although one could not expect a conservative American academic to say so in so many words.

No really convincing explanation, however, is given why the military should be located at some fixed 'middle point' in the class structure. Empirical studies of the class origins of army officers in the Third World on the whole confirm that officers are neither recruited from the ruling or upper classeseven in countries like Brazil where the class structure is relatively well developed - nor are many of them sons of peasants and workers. Few of these studies demonstrate, however, that class origins have a significant effect on political behaviour. The important differences between the military juntas of Brazil and of Peru, would for example, be impossible to predict from their class origins, which are strikingly similar (Stepan, 1973, chapter 2).

Something akin to a process of class formation occurs in military organisations themselves and is visible in their tendency to fissure along the gradations of the military hierarchy. Coups are often the product of particular officer peer groups with similar rank, training, career experience and sources of grievance, such as the Free Officers who brought the military into power in Egypt; the Eighth Graduating Class prominent in the Korean coup of 1961 ; the Majors and Captains and Lieutenants who staged coup and countercoup in Nigeria in 1966; the Lieutenants who belonged to the Tenentismo movement in Brazil in the 1920s and 1930s; and the Captains and Majors who organised the Portuguese and Ethiopian military revolutions of 1974 . Such fissures tend to occur precisely because military organisations are at the same time hierarchies in which rank and career create shared interest and experience between officers of similar rank; and power structures in which the tension between upper and lower levels of command is difficult to contain.

Most armies reproduce the two class division of capitalist societies in the cleavage between officers and the men over whom they exercise command. Again there are numerous examples of military revolts from the ranks, some with momentous political consequences: the sergeants' revolt and naval mutiny which precipitated the assumption of power by the officer corps in Brazil in 1964; the East African mutinies of 1964 which almost (but for British intervention) destroyed the newly independent regimes in Kenya, Tanzania and Uganda and contributed directly to the rise to power in Uganda of Amin; the coup of July 1966 in Nigeria which was as much a revolt of NCOs against the military command as it was a coup of Northerners against Ibo control of army and State; the revolt by ordinary soldiers in Sierra Leone who in 1968 locked up their entire officer corps and handed power back to civilians; and the Portuguese and Ethiopian military revolutions of 1974 the organisers of which acted under strong pressure from their own rank and file (in Ethiopia ordinary soldiers even put their officers under guard until they agreed to act on their behalf). 
Military structures, in sum, generate cleavages that resemble class conflict in that they are generated in a systematic way through the social relations of force ${ }^{1}$ by the way men are fitted together in large-scale organisations around a weapons system designed to produce a certain 'output' of violence.

Such cleavages make it impossible to assume that the military is a monolithic institution or that its role is always conservative. Groups of middle-level and junior officers have sometimes developed radical political programmes: (the Tenentismo movement in Brazil in the 1920s, the Free Officers in Egypt in the 1950s, the Armed Forces Movement in Portugal and the Derg in Ethiopia in the 1970s).

Revolts from the ranks can be still more revolutionary in their potential than peer group interventions. The turning point in the Russian Revolution of 1917 was when the ordinary soldiers refused to turn their guns on the striking workers and joined them. The movements initiated by the Derg in Ethiopia and the Armed Forces Movement in Portugal would probably have been less sweeping without the active pressure and participation of the military rank and file.

Yet military revolts also tend to provoke reaction by the hierarchy. Both Nigerian coups of 1966 though initiated from below, were taken over in the one case by the military Supreme Commander and in the other by the most senior Northern officers. Among the reasons for the Brazilian coup of 1964 was the officers' alarm that the government had failed to deal firmly with mutinies which could have threatened the military institution itself. And what above all persuaded the army officers finally to divert Portugal from its revolutionary course in late 1975 was fear of the consequences of growing indiscipline among the rank and file. As the then Chief of Staff of the Portuguese armed forces, General Fabiao, put it in October 1975, when commenting on the rank and file organisation, Soldiers United Will Win (SUV), "the SUV has a certain strength. But I have reservations, because it is a horizontal organisation and in the army we have a vertical organisation". (Economist, 1975).

Although the social relations of violence themselves thus generate impetus both for military radicalism and for military reaction they are by no means a sufficient condition of either. The Russian Revolution was a revolution because soldiers joined the workers and peasants they were brought out to suppress and not the other way round. In some circumstances army revolt may amount to little more than narrow trades

1 Though they do not, strictly speaking, arise from the exploitation of soldiers as a workforce frem which surplus value is extracted; but from their domination in a hierarchy of power relationships controlled by their superiors. unionism: being easily suppressed because of the absence of wide social support or, like the East African Mutinies of 1964 , as a result of external intervention; bought off by better pay and conditions of service; or (if successful) turning the army into a machine for the extortion of tribute by the new lumpen-militariat as in Amin's Uganda or Batista's Cuba. For soldiers and officers who rebel against the hierarchy always have the option of expropriating the latter for their own benefit rather than seeking to transform society. They are unlikely to choose (or indeed think of) the latter unless external class forces also impel them to do so.

Just as the military is not, because of its institutional distinctiveness, purely and simply the mailed fist of the ruling class; so on the other hand military upheavals cannot by themselves bring about class transformation unless they are associated with mass struggle outside the narrow confines of the military bureaucracy itself. Military revolutions are often little more than revolutions from above, enhancing the role of the State rather than transforming society. The natural heirs of the Tenentismo movement, for example, are the Brazilian generals of the 1970s. In Egypt the social transformation achieved under Nasser was in the final analysis rather limited and is now being reversed under his successor.

Up to this point I have left out the conflicts of community, tribe, religion, culture, language and nation (or sub-nation) which are often also associated with military upheavals. These are in part the residue of pre-capitalist social formations. But in their present form they are as much the product of the uneven development of capitalism and of the State, which characteristically incorporates some groups more fully than others and sets in motion struggles for scarce state-allocated resources-be they jobs, power, development expenditures or military recruitment and promotions.

Nowhere-because of the lack of fit between imposed state superstructures and pre-capitalist formationsare such conflicts more evident than in sub-Saharan Africa. Yet in few parts of the Third World can they be completely ignored. Religion-Christian versus Moslem as in the Lebanon, Ethiopia and the Philippines, different Moslem sects as in Syria or the Sudan-race or tribe-for example, military recruitment as a basis of Malay hegemony in Malaysia, Tutsi repression in Burundi or Bedouin dominance in Jordan-and region-as in the conflict between sierra and coast in Ecuador or the regional balancing of power in the Brazilian army-have all been major factors in military struggles.

Such cleavages do not obliterate military and class relations, but interact with them. In my own case study of The Nigerian Military (Luckham, 1971a), I 
took one of the most extreme examples of ethnic and regional fragmentation of the military and demonstrated that this could also be accounted for in terms of the army's organisational cleavages, the social relations of force. The distribution of power in the military hierarchy overlapped with regional and ethnic differences in such a way that ethnicity became a symbolic master key that unlocked the contradictions of both army and society at the same time in the two coups which took place in 1966. Depending on the recruitment base of the military, the demographic structure and geo-politics of the country and the nature of uneven development, several other variations might be theoretically possible.

The military is also riven by the contradictions between those forces which hold together the national class structure and those which link classes together internationally. Armies are kept in operation by the international arms trade. Yet the surpluses with which arms are purchased are appropriated nationally. Soldiers fight external wars or at the very least keep themselves in a state of preparation for them. Yet they are also the agents of internal repression; indeed in some countries that is virtually their only function. Professionalism is an international ideology disseminated by the military assistance programmes of the advanced countries. Yet army officers play out their careers in national military establishments and are not as internationally mobile as the managers of multinational corporations.

Military training makes army officers peculiarly susceptible to international influences. They often attend courses abroad at some stage in their military career: Latin American officers for the most part in the USA or in US-sponsored institutes such as the inter-American counter-insurgency school in Panama; English speaking African officers in Britain and other countries of the Commonwealth like Canada, Australia, India or Pakistan, but also in the USA: French speaking Africans in France. Military academies and training schools are often modelled on the metropolis, sometimes indirectly as in Nigeria, where the Military Academy was set up with Indian advice and technical assistance, thus passing on British professional values and modes of military organisation at second remove. The socialist countries have likewise recognised the importance of military training for transmitting their international influence; not only in countries where it supports an ongoing transition to socialism (Chinese assistance in the reorganisation of the Tanzanian military or Cuban training missions in Angola) but also in countries where such a transition is more remote (Russian assistance to Uganda and Chinese to the Angolan FNLA).
The implications of military training and assistance programmes for external dependence are easy to see. They train soldiers in the use of the technologies of the donor countries. They give sustenance to the social relations of force around which the professional armies of both metropolis and periphery are organised. They create networks of professional contacts both with metropolitan military institutions and among course-mates in different peripheral countries. And they are often explicitly intended, like US counterinsurgency courses, (or indeed Chinese guerrilla instruction) to promote the political philosophy and interests of the country which provides the training.

They also transmit into the Third World elements of the major class contradictions of the advanced capitalist societies. On the one hand military professionalism means mastery of a range of skillsof management, of using, maintaining and controlling weapons, of technology, communication and transport-developed in parallel with the expansion of capitalism. At the same time these technical and managerial elements of professionalism are in tension with its heroic elements. The latter are a residue of feudalism, but continue to play a critical role in modern armies because they legitimise the military hierarchy. ${ }^{2}$ Thus even these feudal elements are transmitted into the Third World. Pomp and circumstance and the notion that 'officers are gentlemen' seem to be universal aspects of military culture be it in Thailand, Zambia or El Salvador.

The officer and gentlemen ethic is often used to create a special niche for the military in the national class structure. In Nigeria, for example, (Luckham 1971a chapter 4) it is used to assert a distinctive military sphere of values in which social status is not allocated in accordance with the criterion of educational achievement which prevails among other elites (and according to which army officers measure up poorly). The officer corps is thus set apart from the class structure as a whole, yet articulated with it, corresponding with the military's interstitial position both as the mailed fist of the dominant class or classes and as that part of the state superstructure which holds a national society together in periods of class conflict or international crisis.

The effects of international military links can sometimes, however, be quite the opposite of that intended by their sponsors. For example, in the counterinsurgency training organised by Western powers military intellectuals read and transmit to their colleagues the doctrine of the 'enemy'-Mao, Guevara, Giap or Fanon. When the military role is

\footnotetext{
2 For the perceptive analysis of this contradiction within the mainstream of bourgeois military thought see Janowitz (1960).
} 
redefined in the direction of domestic repression rather than external security the contradictions to which these authors call attention begin to emerge. Doctrines of 'revolutionary war' politicise officers both in the direction of the radical right and of the radical left.

Putting down strikes, demonstrations and guerrilla uprisings acquaints army officers with the grim realities of poverty and strife in their own country's rural areas and urban slums. These are not perceived, however, in the abstract but from a particular vantage point in the military hierarchy and class structure, creating a deep ambivalence. On the one hand it is feared that the disorder will get out of hand, and suspected that it is manipulated by international Communist subversion; and tough-minded new doctrines of 'national security' develop. On the other, radicalisation of some sectors of the officer corps occurs, based on the feeling that domestic repression is not the job of the army and threatens to destroy it by bringing it into contact with class conflict. The Majors who staged the January 1966 coup in Nigeria and the officers of the Derg in Ethiopia were alienated by their experience in putting down strikes; the Peruvian military leaders espoused a programme of reform in order to deal with the real social problems they saw as responsible for guerrilla uprisings and to keep the military institution free of the taint of domestic repression.

The contradiction between the two variants of professionalism - that of conventional warfare and that of counterinsurgency-corresponds to an important tension in the class structure of a dependent social formation. On the one hand the techniques and organisational blueprints of advanced countries are transferred to the Third World, interlinked with arms sales and industrialisation. On the other the armies and class structures of peripheral countries do not just become those of the advanced countries writ small, as they have been profoundly distorted by their contact with the latter.

Domination at the periphery requires different relations of force from those in use in the metropolis. Yet this sometimes conflicts with the vested interests of professional soldiers in more conventional military functions. Thus the Peruvian junta which took power in 1968 at the same time that it increased national control over the economy also reasserted the military's role in external defence by buying foreign military hardware of a kind which the civilian regime (under US government pressure) had denied the soldiers.

One may, in conclusion, see two contrapuntal themes in military professionalism in the Third World: on the one hand, military nationalism directed towards the creation of an internationally effective nation- state supported by a well developed conventional army, increasingly linked through its arms purchases to the international economy; on the other, international pressure for political 'stability' at the periphery, requiring an internally powerful state machinery and enlisting military commitment to doctrines of 'national security' legitimising its role in internal repression. These themes are interlinked and contradictory. Both are present in military ideology and tend to be associated with conflict between opposed groups of army officers.

\section{Military hierarchy, repression and international clientage}

Power grows out of the barrel of the gun

the gun on the tank

the warhead on the missile

but also out of the shout of the sergeant-major the pronunciamento of the junta the whisper in the Pentagon

Weapons are mute unless organised in a framework of social relations which determine how they are used and against whom, social relations which can be analysed at at least three levels: the system of command established within military organisations themselves; the system of domination established through the state apparatus; and the struggle for international power and spheres of influence between nation-states.

Neither their own arms nor their diplomacy are enough to assure the nation-states of the Third World of protection from foreign interference or from the mass destruction of their citizens. They live in a world in which the techniques of force are internationalised to such an extent that they pose a common threat to the entire human race, yet are by no means under effective international control. This much the developing countries share in common with the remainder of the world. But they are further disadvantaged by the fact that the precarious balance of power through which some semblance of international peace is maintained is one which on the whole reproduces the dominance of the large industrial powers over the Third World.

In the Third World both army and state were in a real sense created or restructured by the expansion of the central capitalist powers. Their military hierarchies are based on imposed organisational blueprints. The state machinery as a whole is weak, narrowly based and as much the artefact of international as of national domination. And to shore up its fragile structure the military function is inverted: the armed forces being more often used to repress internal dissent than to maintain international security. 
There is no more eloquent testimony to the internationalisation of the relations of domination than the uniformity of certain characteristics of professional armies: the hierarchy of ranks, the exclusiveness of the military brotherhood, the emphasis on rituals and emblems of rank, the codes of honour, the class distinctions between officers and other ranks. Part of this can be accounted for by the fact that a small number of models-basically British, French, German and American-have been consciously transplanted in the Third World. But where other transplants like the ill-fated 'Westminster model' of parliamentary democracy did not take root, military organisations flourished. Organised force is essential for the reproduction of modern nation-states, voting is not.

Nevertheless armies are seldom monolithic institutions on which members of ruling classes can always rely. The use of military force to repress opponents of the regime or to settle struggles for political power often moves the conflict into the armed forces themselves, accentuating their internal contradictions and precipitating coups, mutinies and power struggles.

Military violence itself tends to become a major problem. The memory of the My Lai massacre by American troops in Vietnam-and other massacres like it which surely took place but went unrecordedof French torture in Algeria, of Russian military repression in Eastern Europe and the present realities of British military occupation in Northern Ireland remind one that this problem is by no means confined to the armies of the developing countries.

The boundary between legitimate military force and illegitimate violence is always difficult to draw and is sometimes deliberately obscured both by military leaders and by members of the ruling classes with whom they are associated. However strongly denied internationally, for example, it is clear that there was military participation (by, among others, the RPKAD-the Army Para-commandos) (Caldwell: 14) in the massacre of PK1 (Indonesian Communist Party) members and sympathisers in 1965-66; in the massacres of Ibo civilians in Northern Nigeria in 1966; in the kidnapping and murder of 'subversive elements' by grupos militaros in Argentina, not to mention similar groups which have at various times operated in Uruguay, Brazil. Chile, Guatemala, Uganda, Burundi and no doubt one or two other countries where they have been less well publicised. At the very least the military commanders and governments involved have condoned violence by failing to take action against it; often they have tacitly encouraged if not actively ordered it. Conversely, however, military violence has sometimes been turned against authority: engulfing the army command, the government (even if it is a military government), the ruling class and even in some extreme instances (Nigeria in 1966-67, or Zaire in 1960) the entire structure of the State itself.

The majority of the countries of Africa, Asia, the Middle East and Latin America are under military rule. Still more of them have experienced military intervention or periods of military rule at some point or other during the past $\mathbf{3 0}$ years. And if one adopts broader criteria there are scarcely any where organised military force has not been used to keep in office or to change the regime or ruling class during the past three decades.

Against this background most of the things social scientists have to say seem exceedingly banal. Much of the existing literature takes as its starting point the problem of assuring 'civilian control' over the military establishment : which can be looked at over a whole continuum of military participation in politics, ranging from gentlemanly bargaining over strategy or appropriations, outright blackmail of the regime, participation in the reshuffling of ruling elites right through to direct military control of all the major political institutions of a society (Finer 1962).

The absence of civilian control is only a 'problem', however, when contrasted with an idealised view of the relationship between soldiers and governments in the advanced bourgeois democracies. It is not an especially useful way of looking at the political institutions of Africa, Asia, the Middle East and Latin America, where military participation rather than civilian control might be viewed as the 'normal' state of affairs. Nor does the idea of a continuum from civilian to military take us very far. To be sure, the difference between a military establishment which intervenes as a 'moderating power' to resolve conflicts between civilian factions as in Brazil before 1964 and one which attempts permanently to substitute itself for parts of the state superstructure, to become the State as it were, as in the same country after 1967, is important. Yet to view this as just a change from less to more military participation in political life is superficial, for the military's formal participation in politics is less important than the question of how far the state superstructure is or is not held together by organised coercion. To what extent do those who control that superstructure rely on repressive rather than ideological mechanisms to establish their hegemony?

The distinction between civilian and military regimes may well be less important than the similarities in the way they govern. Take a country like the Philippines where, under a civilian regime civil liberties have been curtailed, the media browbeaten, trade unions deprived of the right to strike, opponents of the 
regime repressed. There is intensive surveillance by the police and military intelligence networks, internal warfare is waged against a dissident minority group, the military is frequently consulted about major government decisions, martial law is in operation and political offences are tried before military rather than civilian tribunals. The extent of repression and its methods differ only in detail from that practised in other Third World countries such as South Korea, Indonesia, Taiwan, Sri Lanka or Pakistan; Brazil, Argentina, Peru or Uruguay; Iran, Iraq, Egypt, Syria or Jordan; Senegal, Ghana, Zaire or Ethiopia; be they formally under civilian governments or under the military and whether the regime is of a conservative or progressive political tendency.

Coups and military regimes are, to be sure, the prevailing trend in the Third World, and this is hardly surprising. For when organised coercion is the main basis of state power, coups are to be expected merely because more 'democratic' methods of transferring power between different fractions of the ruling classes cease to operate. But struggles to gain or to remain in power can also be waged by assassination, mob violence, surveillance and terror by the secret police, bribery and the skilful dispensation of political patronage. Frequent coups may betoken instability in the framework of the State-but not necessarily more so than votes of no confidence, reshufflings of cabinets and frequent elections in bourgeois democracies. Like the latter they speed the circulation of elites and the realignment of fractions of the ruling classes more often than they bring about fundamental change in the organisation of state power and its allocation between (rather than within) social classes.

The coup, then, is to some extent a bogus problem. Rather than improvising explanations of its occurrence it is better to give attention to different questions. To what extent do those who control the state machinery rely on repressive mechanismsincluding army rule--to secure their domination? Is the increase in coups and military regimes part of a more general restructuring of power in the periphery in the direction of greater authoritarianism and less reliance on ideological controls and popular participation? If so, what are the reasons for the change? Which institutions and social classes does authoritarian government benefit, both nationally and internationally? How far is it precipitated by the internationalisation of the capital, power and military influence of the core capitalist countries? Does it make things more (or less) difficult for those who wish to implement reforms like the redistribution of wealth and productive resources or disarmament? Does it create the conditions under which such changes can only be effected by revolutionary change, the smashing of the entire repressive apparatus of the State? What contradictions exist within that apparatus and how can best use be made of them against state (and military) repression?

In Karl Marx's classic analysis of Bonapartism it was recognised that in periods of acute crisis or of historical transition between modes of production members of the ruling class would often be prepared to accept authoritarian government by a state machine over which it had relatively little direct control: the bourgeoisie would sometimes sacrifice its own class rule in order to secure the political stability on which the smooth functioning of a capitalist economy and its own class interests depend.

Bonapartism however is not a magical category into which the analysis of the military can be hammered. The historical circumstances of the present-day Third World bring together a different combination of elements from that which prevailed in nineteenth century France. The crisis of hegemony suffered by ruling classes is permanent and endemic rather than temporary and exceptional. Uneven development superimposes all the contradictions between centre and periphery, capitalist and pre-capitalist social formations, class and tribe, region, religion and nation; and makes it all the more difficult for any single ruling class or fraction thereof to establish its ideological claims to rule.

Add to this the effects of a colonial situation in which an alien ruling class had to rely on state repression to secure its domination. And a process of decolonisation from which there emerged a disjuncture between the national ruling class on the one hand and the economically dominant class with its commanding heights in the boardrooms of internaticnal firms on the other. This gives the crisis of hegemony a peculiar neocolonial twist. For it has retarded the formation of home-grown bourgeoisies and made it more difficult for the latter to function as effective ruling classes able through their policies to exert control over the national economy. But at the same time it creates a problem for the representatives of international capital who have to find ways of influencing policy and the political structure in peripheral countries, despite their inability to act directly as a fraction of the ruling class.

On the face of it the military seems to meet the political requirements of international capital under these troubled circumstances almost better than any other institution. A powerful, relatively autonomous state apparatus-buttressed by military coercionprovides a framework of stability and predıctability within which it is relatively easier for multinational capital to operate. Further, the fact that the military usually depends for its weapons purchases on international purchasing power earned in the world 
market and appropriated through the State tends to cement the alliance with international capital. In the same measure that external penetration weakens the class structure, it increases-through arms supplies, military assistance, and political support-the military establishment's size, claims on productive resources and autonomy relative to other fractions of the ruling class.

Yet to postulate in these general terms that the military appears to fit the political requirements of international capital - stability and a solution to the problems created by international capital's inability to act directly as a ruling class-does not mean that in any given country it will in fact carry out these functions; or do so in a uniform way from one country to another. To begin with, the military and military regimes are hardly ever in a simple sense the political servants of international capital or of great power governments. It would be quite grotesque to label Colonel Gaddafy of Libya, Lt. Colonel Haile Meriam of Ethiopia, the members of the Peruvian junta or indeed General Idi Amin as the agents of imperialism. Even the most reactionary Latin American regimes have a degree of autonomy: witness for example the edifying spectacle of the governments of Argentina, Brazil, Chile, El Salvador and Uruguay threatening to turn elsewhere for arms and military assistance if President Carter continues to cut back aid to countries with a record of violation of human rights.

Indeed, the military's own institutional and material interests lie in the direction of a strong nation-state with control over the surpluses generated in the national economy. This determines the class project carried out by the military in two main ways. First, through the compact established between the State and international capital in which the military has a direct interest as a state institution and an indirect interest through its linkages with the international arms economy. Second, through the role of organised force in resolving-or rather in repressing the symptoms of - the crises generated under different conditions of dependent capitalist development.

Accordingly, in Table 1, I attempt to show how different patterns of incorporation in the world economy shape the varying class projects of the military establishment. The first two patterns set forth in the Table arise in economies which are based on the production of raw materials for the world market, though it makes a considerable difference whether these are produced (like many agricultural commodities) by numerous indigenous petty producers; or are extracted (like most minerals) through large investments of foreign capital. The third and fourth patterns are determined by the nature of a country's process of industrialisation- -whether by import-substitution or by the export of cheap manufactures produced by low-cost labour.

Armies and military regimes are seldom directly subservient to foreign capital. Even in countries whose economies are based on primary products extracted and sold abroad by foreign corporations, they often take up natural resource ideologies (Fortin); and favour state expropriation of foreign capital to the extent this can be achieved (as by the oil producers) without serious damage to the economy's international earning power. In industrialising countries the same factors incline the military towards state investment and regulation of the economy. Such regulation need not interfere with the compact established with international capital and may indeed create a new, more organic symbiosis between the State and multinational corporations. Even when the major means of production are no longer in foreign hands militarism and state capitalism together may still reinforce the integration of the national economy and its class structure in the circuits of the international economy: because foreign exchange still has to be earned to pay for armaments, technology and the expansion of the state and military bureaucracy.

Few countries fit fair and square into any one of the categories in the Table. Indeed, the military often plays a critical role in the transition from one pattern to another. The crisis which led first to the rise to power of the Allende regime in Chile and then to its overthrow by the soldiers in 1974 was, for example, brought on by the exhaustion of the process of import-substitution and the international forces set in motion by the government's expropriation of the foreign copper monopolies. In response to these external forces the military government has adopted economic policies-economic liberalisation, sale of state enterprises, the curtailment of importsubstitution, withdrawal from the Andean Pact -which virtually amount to a reassertion of its traditional position in the international division of labour as a raw material producer.

Further, it is not necessary to assume that the class project the military finally takes up is necessarily agreed in advance or even understood by the officer corps, still less their men, nor that it will be stable. Periods of crisis bring major shifts in the way the military interposes itself in class conflict, which are usually accompanied by violent internal struggles. The social origins of the soldiers who win such struggles, their civilian allies and their original intentions will have some influence on the class project the military undertakes, but may be distorted by the circumstances with which they have to cope once they take power. Examples are not difficult to find: the Nigerian army intervened to establish 
national unity in 1966 but broke up into tribal and regional factions six months later; the Chilean military seized power with the active support of the national bourgeoisie in order to halt what was perceived as a process of national disintegration, and ended up restoring the dominance of foreign monopoly capital; the soldiers who took power in Brazil in 1964 quickly dropped their programme of economic and political liberalisation in favour of state-sponsored industrialisation under an authoritarian regime.

Although the crises of dependent capitalist development provoke military repression, this repression does not necessarily establish political order. Sometimes the military's weapons have simply turned conflict into more bloody conflict: witness, for example, the effects of military violence in Uruguay, in Bangladesh just before its war of liberation from Pakistan or indeed in Northern Ireland. Or the military itself has become deeply divided-as in Nigeria and the Lebanon before and during their respective civil wars-and thus unable to stand above the conflict. Nevertheless the fact that military force settles things in the last resort is critical, particularly in societies in permanent crisis, where the last resort is always close at hand.

Not can one automatically assume that the military will intervene in these crises as the compliant ally of the dominant classes. Its internal fissures, as we have already seen, may create radical as well as reactionary tendencies both in the officer corps and among ordinary soldiers. On a number of occasions the military establishment has sided with the periphery against the centre-as in some African states where the recruitment base of the army has traditionally been in the less developed parts of the country-or with labour in its struggles with capital -as in the alliance between sections of the army and organised labour in Peronist Argentina in the 1940s.

Yet although particular fractions of the military elite may intervene on behalf of peripheral or excluded classes and groups in times of crisis, the military establishment as a whole has a vested interest in what military ideologists call 'national security' and what its opponents call state and class domination.

The natural response of professional soldiers is to suppress class struggle when it appears because it divides the nation, undermines the international economic standing of the economy-causing flights of foreign capital-and imposes certain real costscasualties, disruption of routine, threats to its structure and its monopoly of organised force-upon the military establishment itself.

Let us turn, therefore to the interrelation between the international system and armed force. This can be analysed at a number of levels. In the first place a world in which conflict is endemic and force governs the relations between nation states enhances the influence of military organisations. More than 30 years ago Harold Lasswell (1941) suggested that growing international conflict would increasingly turn the world powers into "garrison states" in which the influence of military managers of violence would predominate: though he omitted to say that this conflict can sometimes itself be the consequence of the influence of these military managers in whose interests it is to exaggerate threats to security.

International insecurity contributes equally much to military influence at the periphery. The armed forces are large and influential in most countries at the edge of the cold war, like Greece, Turkey, Iran, Thailand and South Korea; and also in countries at the nodes of regional conflict as in the Middle East and the Horn of Africa. Military coups have frequently swept aside civilian governments which have failed (in the soldiers' view) to provide adequately for their country's security: for example the overthrow of the Egyptian monarchy by the Free Officers after humiliating defeats suffered at the hands of Israel; or the 1969 coup in Somalia which swept aside a civilian government which had pursued the border conflict with Ethiopia with less enthusiasm than the soldiers desired. Soldiers are also quick to react to the international aspects of internal struggles. For example the contagion effects between military coups, such as those which swept through west and central Africa in 1965-66. Or the spread of military garrison states in Latin America in the 1960s and 19\%0s; responding on the one hand to the establishment of socialism in Cuba and the spread of revolutionary movements across national boundaries; and on the other to the transnationalisation of American counterinsurgency training and doctrine.

As with military intervention in the internal politics of a country, so too there is a whole continuum of external intervention: from diplomatic pressure, economic aid and military assistance programmes; various forms of blackmail such as threats to withdraw economic and military assistance; covert subversion and the destabilisation of regimes in the style of the CIA or KGB; reassurances of recognition and support to coup-makers if successful; actual material support for a coup, or alternetively support in putting one down; military assistance and advice in counter-revolutionary operations; taking direct part in such operations (the US in the early stages of the Vietnam conflict); direct participation in a revolutionary war (the Chinese in Korea or the Cubans in Angola); through to actual invasion by troops of the intervening power (the US in the Dominican Republic and in Vietnam, or France and Britain in the Suez Crisis). 


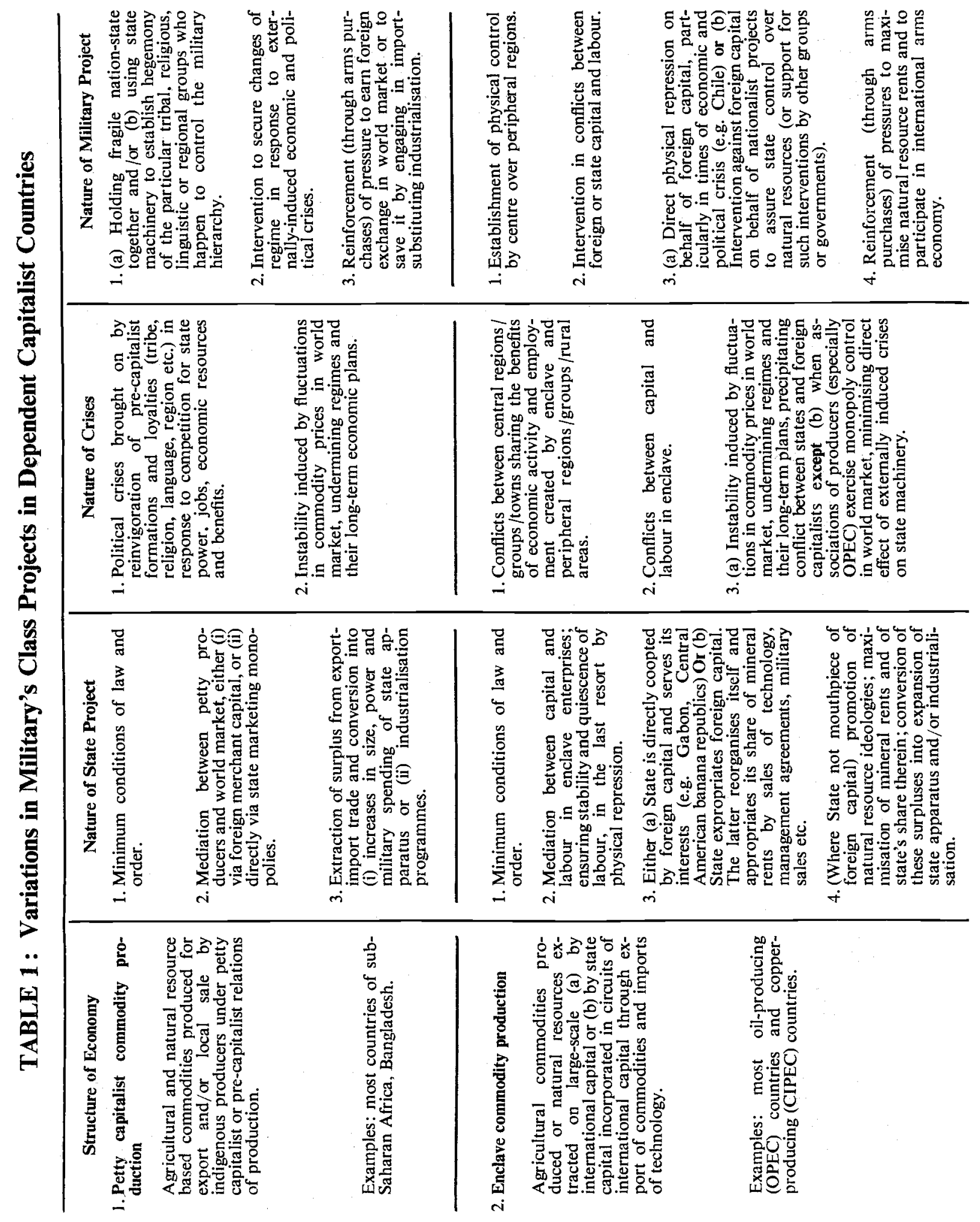




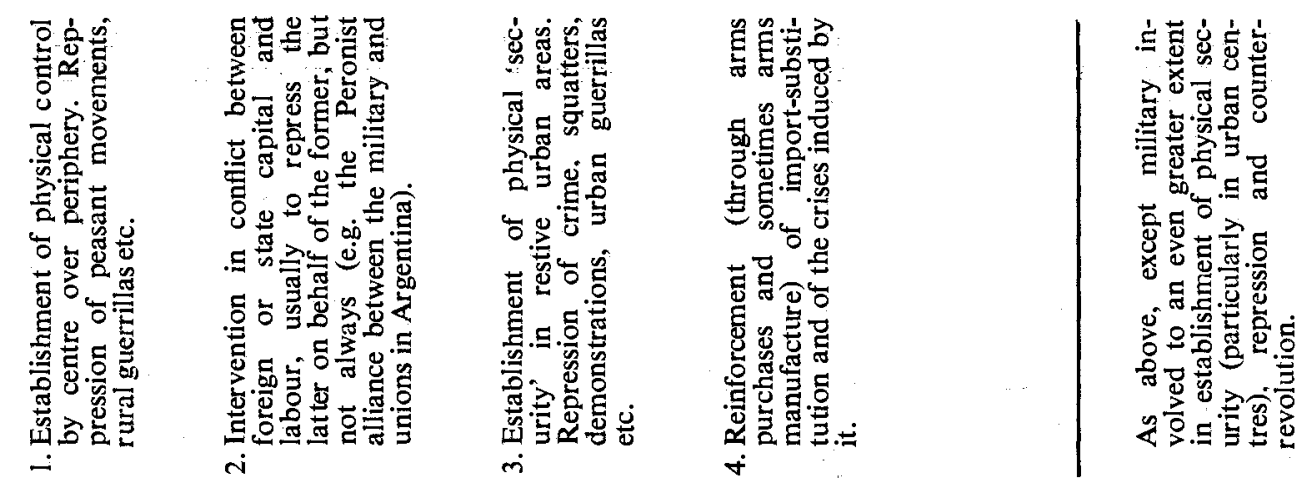

\begin{tabular}{|c|c|c|c|}
\hline 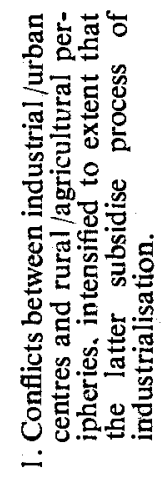 & 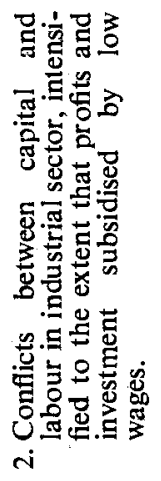 & 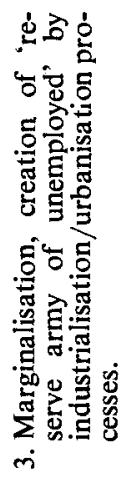 & 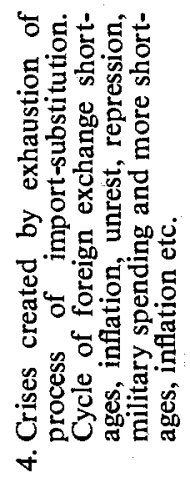 \\
\hline
\end{tabular}

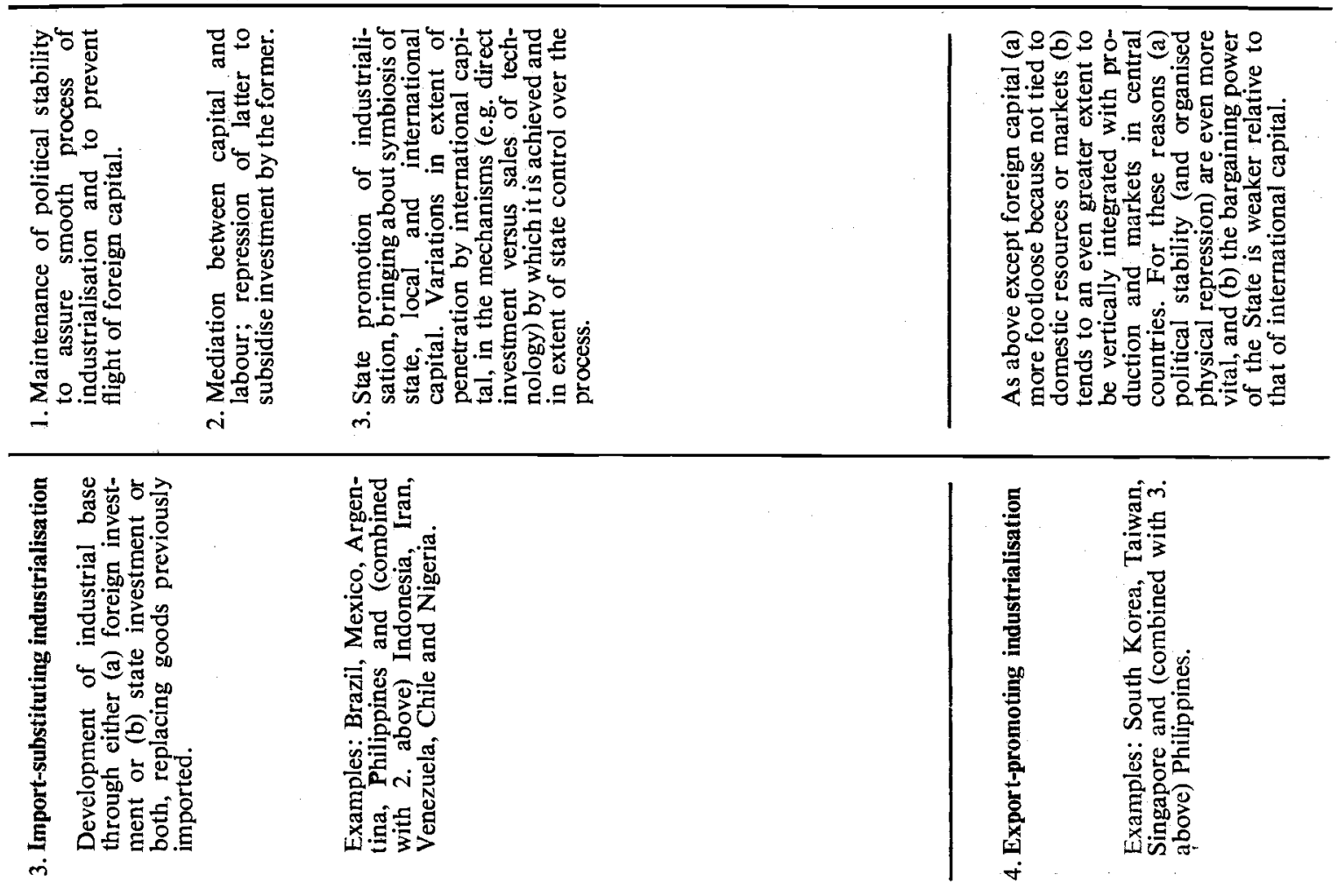


Yet one cannot measure the effect of external pressures on the military, the class structure or the political system as a whole solely by the level to which overt foreign interference has actually been pushed. In some countries, like Chile, intervention may have taken place precisely because the contradictions are sharper than elsewhere and the hegemony of imperialist powers less secure. In others the class structure and internal political forces may be self-sustaining and direct intervention unnecessary. The arms trade and discreet military assistance programmes are often all that is required to keep the professional military establishment in operation and the stability of the political system within tolerable limits. And in others again, like Iran, Indonesia or Zaire external penetration may be massive but multifaceted, so that to take one aspect alone such as support for a coup, covert CIA activities, foreign aid and investment, military assistance, or diplomatic pressure, may give an incomplete picture of foreign influence because all are important together.

Conversely, however, direct intervention has sometimes created more contradictions than those it represses. The Suez crisis, the American intervention in Vietnam and the South African invasion of Angola are perhaps the most glaring examples, but there are several others. Failure to examine abortive as well as successful interventions might lead one to underestimate the limits imperialism faces, the contradictions it creates for itself and the strength of the forces opposed to it on the periphery. These limits arise at a number of different levels.

First, the strength and disposition of anti-imperialist forces themselves: in Vietnam for example, the military effectiveness of the liberation armies and the presence of the Russian nuclear deterrent to discourage escalation of the conflict by the Americans; in Angola the extremely prompt and effective assistance provided by the Cubans and Russians and the reluctance of the USA to risk a diplomatic showdown in Africa by openly intervening.

Second, differences among the major Western powers, as during the Suez crisis, when the disapproval of the Americans and their refusal to support British borrowing from the IMF to halt the run on the pound caused by the crisis, brought the Anglo-French invasion of Egypt to a grinding halt.

Third the internal contradictions by which imperialist powers are sometimes weakened: the bitter opposition to the Suez invasion by the Labour Party; or the economic burden of arms spending by the US government in Vietnam and the gathering strength of the anti-war movement. There are strong pressures impelling the major capitalist powers to intervene in their interests at the periphery. But it would be a mistake to regard them as monolithic and to underestimate the constraints according to which they operate.

Intervention, furthermore, is not exclusive to capitalist powers but has also been an integral part of the struggle against them. External support has been a crucial element in most contemporary revolutions: Russian support (however grudging) for the Chinese revolution; Russian and Chinese assistance in Vietnam; Arab and communist bloc help to the Algerians in their war of national liberation from France; the assistance of the Russians and Chinese and of neighbouring African countries to the armed struggle in Guinea-Bissau, Angola and Mozambique.

Nevertheless such assistance is not without its own contradictions. External aid cannot overcome unfavourable objective conditions; witness for example the failure of Che Guevara to bring revolution to Bolivia. It all too easily triggers off nationalist responses and accusations of 'social imperialism' against the donor: visible already, for instance, in the ambivalence of the Angolans about the continued presence in their country of their Cuban and Russian liberators. Recipients of socialist assistance-however worthy according to revolutionary criteria-are vulnerable to changes in the interests of the donors. The revolutions in Laos and Cambodia were delayed because the Vietnamese gave and withdrew assistance in accordance with the progress of their own struggle. Socialist rivalries-for example Chinese support for the FNLA and Cuban and Soviet for the MPLA in Angola-have sometimes helped to create divisions in liberation movements.

In a very real sense the intervention of socialist countries is also limited and shaped by the constraints of balance of power politics. In several Latin American countries the Moscow-controlled communist parties have been ambivalent toward armed struggle: fluctuating between support for insurrection and for more 'legitimate' activity in accord with the turns and swings of international politics. The support of socialist countries for the revolutions in former Portuguese Africa was covert and limited in quantity until the international political conjuncture became favourable to largerscale involvement after the invasion of Angola by South Africa.

Despite the expansion of capital on a world scale there is little semblance of an international superstructure, comparable to the national state. There are instead only partial international superstructures; some based on region (the EEC, ASEAN etc); some constituting military alliances between states (NATO, the Warsaw Pact and the moribund SEATO and CENTO) and some with 
specialised functions (the UN agencies, IMF, World Bank etc.). These do relatively little to bind the world system together. Indeed military alliances and regional pacts on the whole deepen the main fractures between blocs.

Rather than superstructure it might be more apposite to talk of a 'superstruggle': but for the integrating mechanisms of both of the international economy, which incorporates enterprises and states alike in the circuits of capital, and of balance of power politics which (at least for the time being) prevents the war of all against all.

Although most statesmen and military leaders subscribe to the concept of a balance of power-and thus make it take on the character of self-fulfilling prophecy-it is thoroughly ambiguous. The nature of the nuclear means of mass destruction on which the balance between the central world powers is based is such that balances computed merely in terms of the numbers of missiles, aircraft and nuclear warheads available to each side make little sense. Further, the very ability to participate depends on a very advanced technology and industrial base. The balance thus expresses the competing interests of the ruling classes of advanced industrial countries and the clientage of those of the Third World.

And, further, a balance between societies with diverse modes of production is by no means a balance of equivalents. For its equilibrium is constantly disturbed by the contradictory pressures of capitalist and of socialist expansion towards the periphery. The Russians and Cubans, for example, have made it clear that detente does not in principle exclude assistance to wars of national liberation. Western governments too consider that interventions on behalf of capital are permissible, however much they may protest against socialist interventions. The main constraint is what each side thinks it can get away with-in terms both of international power politics and of domestic support for its policies from one period to another.

Such an international system does not even succeed in providing a political basis for the orderly expansion of capital on an international level; the tools of international economic management having proved woefully inadequate to deal with the current international economic crisis. Still less does it provide a reasonable prospect of peace and of a more just distribution of resources internationally. All the available evidence suggests that arms races will continue, even though in some measure limited by SALT and other such agreements.

Balance of power politics, furthermore, provides only temporary and largely inadequate solutions to the international crises which beset the Third World.
Typically, it is devoted to stabilising the existing situation without getting to grips with the substantive issues, the very real contradictions which underlie conflicts such as the Middle East crisis or the wars of national liberation in Southern Africa.

From a revolutionary point of view struggles for class and national liberation take precedence over international stability for its own sake. Would Vietnam have been liberated by international negotiation? Does it make sense to negotiate over majority rule in Rhodesia, still less in South Africa without a credible threat of revolutionary violence to speed the negotiations along? Can the Middle East conflict be resolved without a just solution for the problem of the Palestine? And do the Palestinians have any way of securing international attention except by hijacking, bombing and raiding?

The very severity of the present international crisis in some ways, however, provides favourable opportunities for the modification or destruction of existing relations of international domination: a nuclear stalemate in which great powers can be played off against each other; internal dissent within the large capitalist powers which makes it more difficult for their governments to pursue expansionist foreign policies; economic crisis which fuels this discontent inside capitalist countries, and, further, makes it difficult for them to finance external military ventures or to subsidise arms sales in order to gain political influence. The same crisis also bringing things to a head in the periphery, concentrating economic grievances and mobilising popular forces (but also increasing the repression by dominant classes).

Yet these opportunities involve very grave dangers both for those who take advantage of them and for the international community as a whole. Would a major escalation of the conflict in Southern Africa with heavy Cuban and Soviet support for the revolutionary forces be worth the risk of a major international conflagration? What is the risk of the Arabs and Israel using the missiles they both now possess against each others' cities? What will happen to international relations if attempts to control nuclear proliferation fail, and countries like Vietnam and Cuba on the one hand and Brazil and India on the other deploy their own nuclear warheads? What likelihood is there that a revolutionary group like the Tupamaros or the Black September could actually acquire their own nuclear arsenal? And-supposing one sympathised with their broad aims-how would one balance the prospective gains from nuclear blackmail against the enormous risks for all concerned, including possible retaliation in kind by neo-fascist groups or by Israel respectively. 
This is a real dilemma for those who wish to change the existing pattern of international domination. On the one hand increasingly dangerous forms of armed struggle and international conflict. And on the other the severe limits of negotiated settlements which start from the existing distribution of power. For the latter have enormous obstacles to overcome in the vested interests crystallised around existing nation states and military organisations; in the international division of labour and patterns of international capital accumulation; in the international arms economy, and in the very complexity of the issues at stake in international conflict. To the extent that attempts to stabilise the existing pattern of international arrangements merely buy time, in which lines of conflict harden and the international production and diffusion of destructive weapons continues, they may actually increase the ultimate danger. Weapons and military organisations-the means of force-are in the international domain, in that their deployment and or use is a matter of common danger and common social concern for all mankind. Yet they are still appropriated and controlled by national ruling classes which use or threaten to use them to reproduce their national power and international interests. This makes social control over their use and conditions of lasting peace almost impossible to bring about without major transformation in the structures of international production, power and force. But the risks of the struggle to bring about such transformation are great and impose heavy responsibilities on those who undertake it.

\section{References}

Astiz, A., 1972, 'The Peruvian Military', Western Political Quarterly No. 4.
Caldwell, Malcolm et al, 1975, Ten Years Military Terror in Indonesia, Spokesman Books, Nottingham

Economist, October 18, 1975

Finer, S. E., 1962, The Man on Horseback, Pall Mall Press, London

Fortin, Carlos, 1977, 'The State and Multinational Corporations in Latin American Natural Resources' IDS Bulletin Vol. 9, No. 1.

Huntington, Samuel P., 1968, Political Order in Changing Societies, Yale University Press, New Haven

Janowitz, Morris, 1960, The Professional Soldier, Free Press, New York

Lasswell, Harold, 1941, 'The Garrison State', American Journal of Sociology, XLVI, January

Luckham, Robin, 1971, The Nigerian Military: A Case Study in Authority and Revolt 1960-67, Cambridge University Press, Cambridge

Luckham, A. R., 1971, 'A Comparative Typology of Civil-Military Relations' Government and Opposition, Vol. 6, No. 1.

Marx, Karl 'The Eighteenth Brumaire of Louis Bonaparte' in Karl Marx and Frederick Engels, Selected Works (Moscow: Foreign Languages Publishing House, 1958) Vol. 1, pp. 243-344

Stepan, Alfred, 1971, The Military in Politics: Changing Patterns in Brazil, Princeton University Press, Princeton

Stepan, Alfred (ed.), 1973, Authoritarian Brazil, Yale University Press, New Haven 